\title{
LINKING ORGANIZATIONAL STRUCTURE, TECHNOLOGICAL SUPPORT AND PROCESS INNOVATION: THE MEDIATING ROLE OF KNOWLEDGE SHARING IN THE IRAQI TEXTILE INDUSTRY
}

\author{
Amal Ghalib Rashid Al-Mamoori and Zainal Ariffin Ahmad \\ Graduate Business School \\ Universiti Tenaga Nasional (UNITEN) \\ 43000 Kajang, Selangor, Malaysia \\ e-mail: amal_rashd@yahoo.com \\ e-mail: azainal@uniten.edu.my
}

\begin{abstract}
This paper investigates the relationships among organizational structure, technological support, knowledge sharing and process innovation and whether knowledge sharing has a mediating effect on these relationships. Based on the survey among employees in the Iraqi textile industry, the results revealed that organizational structure and technological support positively and significantly influence knowledge sharing. Knowledge sharing was also found to be an important mediator between organizational structure, support technology and process innovation. The findings bear implications to the Iraqi government's call for innovation in the Iraqi textile industry.
\end{abstract}

Key Words: Organizational Structure, Technological Support, Knowledge Sharing, Process Innovation

\section{INTRODUCTION}

Process innovation is unique, complex and difficult to control (Gerybadze, Hommel, Reiners, and Thomaschewski, 2010). It describes the activities that are performed at each stage of the development of innovation (Ortt and Duin, 2008). Process innovation is defined as developing a new or substantially improved production process through new equipment or reengineering of operational process (Wong and He, 2003). Capon, Farley, Lehmann and Hulbert (1992) suggest process innovation as tools, devices, and knowledge in throughput technology that mediate between inputs and outputs and are new to an industry, organization, or subunit. Knowledge management can play a pivotal role in supporting and nurturing innovation (Chen and Huang, 2009; Gold, Malhotra and Segars, 2001). Knowledge sharing plays a potentially mediating role in connecting organizational structure and technological support with organizational innovation process. Successful knowledge sharing is believed to have the potential of enhancing an organization's competitive advantage, customer focus, employee relations and development, innovation, and lower costs. Finally, the organizational promotion of knowledge sharing is changing traditional ideas concerning managing intellectual resources and employee work styles by providing new processes, disciplines and cultures, thus constituting an organizational innovation (Darroch and McNaughton, 2002).

Knowledge sharing and process innovation in the Iraqi textile industry are relatively new concepts whereby the industry is dominated by 6 government-owned manufacturers who run the textile factories. The researchers conducted preliminary interviews with the manufacturers and were informed that whereas the factories share common organizational structure, the operations were lacking in technological support and knowledge sharing as they were still using traditional technology and focused on production, not process innovation. Therefore, the purpose of this paper is to examine the possible 
mediating effect of knowledge sharing on the relationship between organizational structure and technological support withprocess innovation in the Iraqi Textile industry.

\section{LITERATURE REVIEW}

\section{Process Innovation}

Today's competitive business environment, innovation is absolutely essential. Superior innovation provides companies with opportunities to grow faster, better, and smarter than their competitors. Ultimately this can enable a company or organization to influence the direction of its industrial sector (Davila, Epstein and Shelton, 2006). Cetindamar and Ulusoy (2008) defined "innovation" as the process leading to the adoption and diffusion of new technologies with the express aim of creating new processes, products and services. Damanpour (1991) defines innovation in a broader way by viewing it as a new product or service, a new production process technology, a new structure or administrative system, or a novel plan or program pertaining to organizational members. Process innovation is viewed as a pervasive and embracing process which includes research, development, and implementation of new ideas and behaviors (Damanpour, 1996).

Extensive literature reviews suggest that process innovation depends on several dimensions: level, driver, direction, source and locus (Crossan and Apaydin, 2010). Level explains the split between individual, group and firm's processes. Driver deals with both, internal and external driver. Internal drivers of the innovation process can be available knowledge and resources. Prajogo, Power and Sohal (2004) identified two types of innovation performance, product and process. These classifications enable the grouping of organizational innovation into product innovation and process innovation. Prajogo et al. (2004) stressed that knowledge management has substantial positive relationship to both product innovation and process innovation. Gerybadze, Hommel, Reiners and Thomaschewski (2010) mentioned that it is important to monitor innovation from different perspectives such as structure related, market related, product/project related, process/performance related and culture related.In considering innovation as a process, unitary sequence model is used to explain process innovation (Gopalakrishnan and Damanpour, 1997).

\section{Organizational Structure}

Organizational structure refers to the formal allocation of work roles and administrative mechanisms to control and integrate work activities (Ghani, Jayabalan, and Sugumar 2002; Robbins 1990). According to Claver-Cortés, Zaragoza-Saez and Pertusa-Ortega (2007), organizational structure can be defined as the result of the combination of all the ways in which work can be divided into different tasks, the coordination of which must afterwards be ensured. Structures that promote individualistic behavior in which individuals, divisions, or functions are implicitly or explicitly required to keep knowledge private have been shown to inhibit effective management of knowledge in organizations (Gold et al. 2001, O'Dell and Grayson 1998).

The knowledge-based view emphasizes the importance in understanding the processes through which organizations access and utilizes knowledge possessed by its individual members (Grant, 1996). Structure can influence knowledge management processes through shaping patterns and frequencies of communication among organizational members, stipulating locations of decisionmaking and affecting efficiency and effectiveness in implementing new ideas (Zheng, Yang and McLean, 2010). Despite inconclusive findings regarding the relationship between organizational structure and knowledge management (Tsai, 2002), a decentralized structure has often been seen as facilitative to knowledge management success (Damanpour, 1991; Deal and Kennedy, 1982; Gold et 
al., 2001). High centralization inhibits interactions among organizational members (Gold et al., 2001), reduces the opportunity for individual growth and advancement (Kennedy, 1983), and prevents imaginative solutions to problems (Deal and Kennedy, 1982). Therefore, it is posited that:

H1. Organizational structure relates positively to knowledge sharing.

Two important aspects of organizational structure are centralization and formalization (Eppler and Sukowski 2000; Jarvenpaa and Staples 2001). Accordingly, organizational structure is construed as a second-order construct encompassing these dimensions. Centralization refers to the locus of decision authority and control within an organizational entity Caruana, Morris and Vella 1998; Ein-Dor and Segev 1982). Centralization of decision making can result in complex and time-consuming communication channels (Bennett and Gabriel 1999), which may introduce distortion and discontinuity of ideas and knowledge as they are passed along multiple levels of authority (Stonehouse and Pemberton 1999). Formalization refers to the degree to which decisions and working relationships are governed by formal rules, standard policies, and prescribed procedures. Smith (2006) argues that organizational structure facilitates the discovery, creation, sharing, exchange, and transference of new knowledge within the organization. It is the main mechanism through which organizations supervise the behavior of employees and coordinate individuals and functions (Holsapple and Joshi 2001; Rapert and Wren 1998). Therefore, it is posited that:

H2. Organizational structure relates positively to process innovation.

\section{Technological Support}

Sher and Lee (2004) indicated technology is certainly conceptually complicated and multidimensional. It exists in several types which include artifact, knowledge, and process. Artifact technology can relate like tools, techniques, and actions used to change organizational inputs into outputs. Similarity study by Tippins and Sohi (2003) show the technological support enhance individual's connectivity and facilitate knowledge structuring and interpretation. According to (Kim and Lee, 2005) show support technology is multi-dimensional and organization must invest in an extensive infrastructure that supports the different kinds of knowledge.

Technology tools for knowledge sharing include electronic bulletin boards, discussion forums, knowledge directories, groupware, databases, intranets, intelligent search engines, personal web pages, electronic mail, virtual conference rooms, libraries, corporate yellow pages, among many others (Alavi and Leidner, 2001; Bender and Fish, 2000). It is evident that technology enables and aids core knowledge activities such as knowledge creation, knowledge sharing, knowledge distribution, and knowledge application (Gold, Malhotra and Segars, 2001). Similarly, it is clear that technology is an integral part of the KM application. Specific technologies play a fundamental role in promoting the KM movement (Barney, 1991). Kharabsheh (2007) draws a very clear relationship between technology and knowledge sharing. Therefore, it is posited that:

H3. Technological support relates positively to knowledge sharing.

H4. Technological support relates positively to process innovation.

\section{Knowledge Sharing and Process Innovation}


Mohd and Zawiyah (2009) defined knowledge sharing as a process where individuals exchange knowledge (tacit or explicit) and together create new knowledge. Knowledge sharing can play a pivotal role in supporting and nurturing innovation (Chen and Huang, 2009). As noted earlier, various scholars have proposed the importance of managing knowledge in the organizations, hence implying that the implementation of KM would be conducive to process innovation. Knowledge creation involves a continuous process through which one overcomes the individual boundaries and constraints imposed by information and past learning, by acquiring a new context, a new view of the world, and new knowledge. By interacting and sharing tacit and explicit knowledge with others, the individual enhances the capacity to define a situation or problem, and apply his or her knowledge to solve the problem effectively (Nonaka, Von Krogh and Voelpel, 2006). Nonaka (1991), and Nonaka and Takeuchi (1995) contend that the concept of innovation and "knowledge creation" are closely related. Along this line, it is generally assumed that the process of innovation consists of an ongoing pursuit of harnessing new and unique knowledge (Subramaniam and Youndt, 2005). Hence, it is posited that:

H5. Knowledge sharing relates positively to process innovation.

\section{Mediating role of Knowledge Sharing}

Effective knowledge management contributes to competitive advantage (Connor and Prahalad, 1996), improved performance (Teece, 1998), and innovation (Nonaka and Takeuchi, 1995).Knowledge resources are an outcome of organizational culture, structure, because knowledge is created, made sense of, and utilized in accordance with a set of cultural values and norms, embedded in structural relationships, For example, knowledge sharing practices are affected by cultural expectations such as what knowledge should be shared with the organization and what should be hoarded by individuals, by structural relationships such as how quickly the knowledge flows through formal reporting relationships. In turn, organizational knowledge reflective of cultural, structural, characteristics of the organization is utilized to help produce new products and services, improve efficiency, and enhance effectiveness (Nonaka, Toyama and Konno, 2000).Finally, the organizational promotion of knowledge sharing is changing traditional ideas concerning managing intellectual resources and employee work styles by providing new processes, disciplines and cultures, thus constituting an organizational innovation (Darroch and McNaughton, 2002). In this light, knowledge sharing can be seen as mediating the relationship between organizational factors and process innovation, hence it is posited that:

H6. Knowledge sharing mediates the relationship between organizational structure and process innovation.

H7. Knowledge sharing mediates the relationship between technological supportand process innovation

\section{Research Model}

The intersection of the resource-based view lays the theoretical grounding for this study. The resource-based view posits that firm competitiveness comes from unique bundles of tangible and intangible assets that are valuable, rare, imperfectly imitable, and sustainable (Barney,1991). Researchers such as Barney(1991), Peteraf (1993), and Wernerffelt (1984) argue RBV views a firm as a bundle of resources and capabilities. Resource consist of tangible components like financial and physical assets like property; plant and equipment; and intangible components like human capital, patent, technology know-how (Grant,1996). Capabilities are "invisible assets", tangible or intangible organizational processes developed by a firm over a period of time that "cannot be easily bought; they must be built" (Teece, Pisano and Shuen, 1997, p.514). It has been widely accepted among scholars and practitioners that organizational context and processes have considerable influences on the 
organizational effectiveness of practices (Zheng, Yang and McLean; Gold, Malhotra and Segars, 2001).A vast number of studies and surveys indicate that there is a positive relationship between an efficient organizational context and effective knowledge sharing and the organizational competitiveness of implement KM. In this conceptual model, the organizational contexts (organizational structure and technological support) as independent variables; knowledge sharing as a mediating variable and process innovation as the dependent variable.

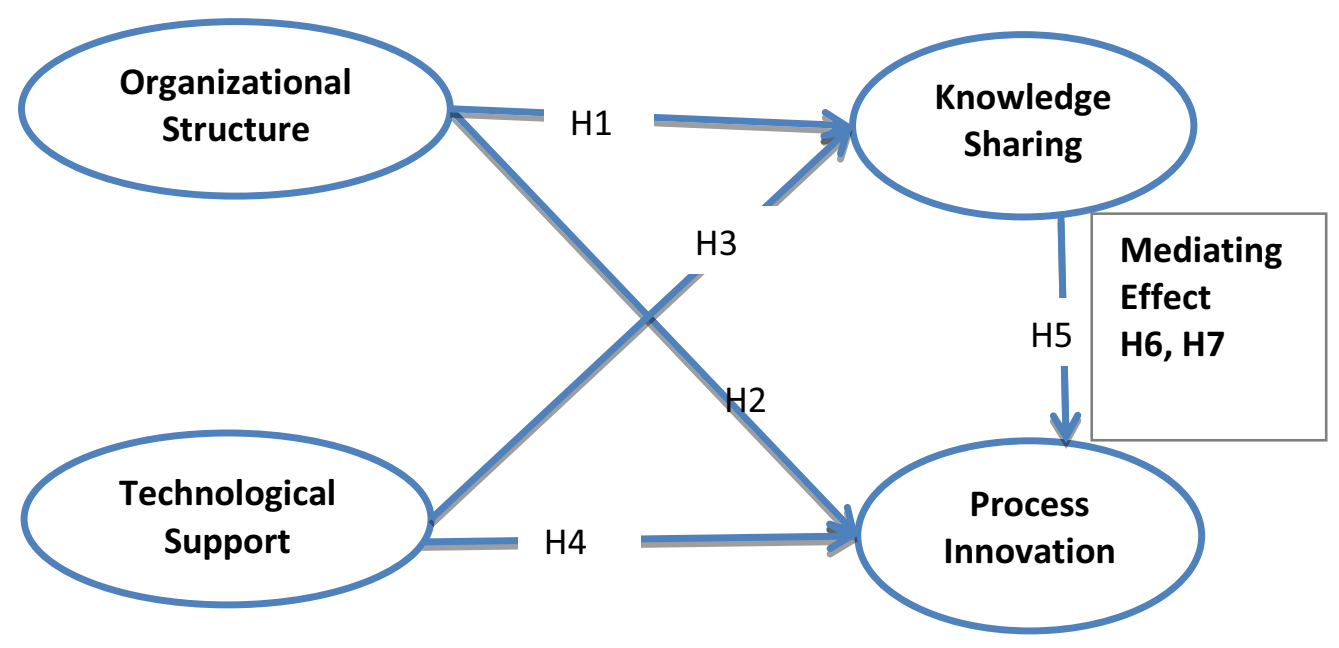

Figure 1. Research Model.

\section{METHODOLOGY}

Based on proportionate stratified random sampling technique, questionnaires were randomly distributed among 361 employees of the Iraqi textile from March to June 2013. Only 350 of the 360 questionnaires were complete and used for Structural Equation Model (SEM) analysis. Survey items were adapted from existing instruments used in past research. Measures of process innovation were based on five items from Hung, Lien,Yang, Wu and Kuo(2011).Ten items to evaluate organizational structure, technological support and knowledge sharing were adapted from Gold et al.(2001).The results of the principal component factor analysis yielded eigen values greater than 1.0, which accounted for $58 \%$ and $65 \%$ of the variance for the independent and dependent variables respectively. 


\section{RESULTS}

\section{Measurement models}

Results from the confirmatory factor analysis demonstrated that all of the scales used in the study formed adequate measurement models and thus provided evidences for the construct validity of the measures. Table 1 shows the fit indices of the measurement models whereas Table 2 shows the descriptive statistics of the constructs.

Table1

Evaluation of Measurement Models

\begin{tabular}{|c|c|c|c|c|c|c|c|}
\hline Variables & $x^{2}$ & $\mathrm{df}$ & $\mathrm{P}$ & $\mathrm{CFI}$ & GFI & CMIN/df & RMSEA \\
\hline \multicolumn{8}{|l|}{ Organizational } \\
\hline Structure (OS) & 7.84 & 4 & .098 & .994 & .99 & 1.96 & .052 \\
\hline Technological & & & & & & & \\
\hline Support (TS) & 8.64 & 6 & .195 & .997 & .99 & 1.44 & .035 \\
\hline Knowledge (KS) & & & & & & & \\
\hline Sharing & 5.20 & 4 & .297 & .997 & .99 & 1.30 & .029 \\
\hline Process (PSI) & & & & & & & \\
\hline Innovation & 12.59 & 5 & .082 & .991 & .99 & 2.52 & .066 \\
\hline $\begin{array}{l}\text { All measurement } \\
\text { model }\end{array}$ & 335.60 & 146 & .000 & .93 & .90 & 2.44 & .064 \\
\hline
\end{tabular}

Table 2

Descriptive Statistics ( $N=351)$

\begin{tabular}{|c|c|c|c|c|c|c|c|c|}
\hline Constructs & Mean & SD & OS & TS & KS & PSI & CR & AVE \\
\hline $\begin{array}{l}\text { Organizational } \\
\text { Structure (OS) }\end{array}$ & 39.16 & 6.43 & 1 & & & & .89 & .67 \\
\hline $\begin{array}{l}\text { Technological } \\
\text { Support (TS) }\end{array}$ & 36.02 & 6.73 & $.80^{* *}$ & 1 & & & .92 & .63 \\
\hline $\begin{array}{l}\text { Knowledge (KS) } \\
\text { Sharing }\end{array}$ & 42.41 & 5.64 & $.61^{* *}$ & $.57^{\star *}$ & 1 & & .85 & .54 \\
\hline $\begin{array}{l}\text { Process (PSI) } \\
\text { Innovation }\end{array}$ & 15.76 & 4.12 & $.56^{* *}$ & $.55^{\star \star}$ & $.46^{* *}$ & 1 & .93 & .59 \\
\hline
\end{tabular}

\section{Assessing Structural Model}

The goodness of fit indices show that the hypothesized model fit the data well .The path coefficients in Figure 2 and Table 2 was used in testing hypotheses 1 to 5 , the indirect effects between the variables were tested in hypotheses 6 and 7. Holbert and Stephenson (2003) indicated specific indirect effects are not calculated by the major SEM software packages, so Sobel test for significant indirect effects are shown in Table 4. 


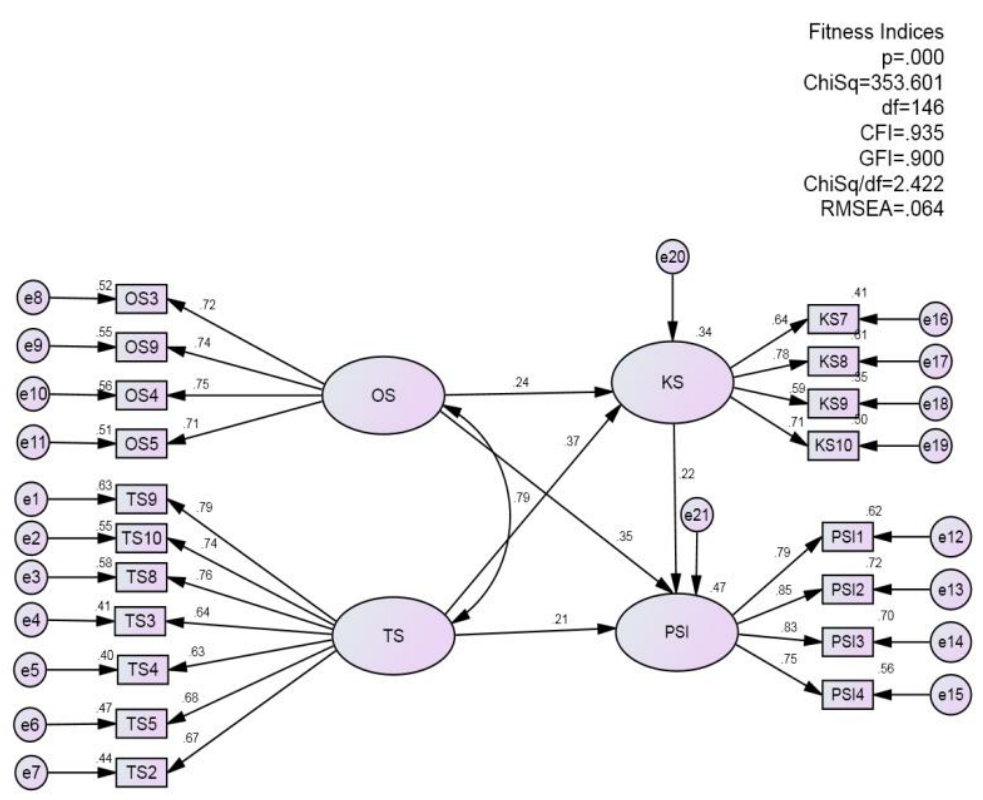

Figure 2.Path Diagram of the Model.

\section{Hypotheses testing}

All of the hypotheses were examined through the investigation of the path coefficients and the statistical significance .Based on the results in Tables3 and4, Hypothesis 1 is supported. There is a significant path coefficient of.24 $(p<.05)$ from organizational structure to knowledge sharing. Hypothesis 2 is also supported. There is a significant path coefficient of $.35(p<.01)$ from organization structure to process innovation. Hypothesis 3 is supported. There is a significant path coefficient of $.37(p<.05)$ from technological support to knowledge sharing. Further, Hypothesis 4 is supported. There is a significant path coefficient of .21 $(p<.05)$ from technological support to process innovation. Hypothesis 5 is supported. There is a significant path coefficient of $.22(p<.05)$ from knowledge sharing to process innovation. From the results in Table 4, knowledge sharing was found to have partial mediating effect between organizational structure and process innovation, and between technological support and process innovation. So, hypotheses 6 and 7are partially supported.

Table 3

Path Coefficients and Goodness-of-Fit

\begin{tabular}{|c|c|c|c|c|}
\hline Path & $\begin{array}{l}\text { Standard Path } \\
\text { Coefficients }\end{array}$ & CR & $P$ & Goodness-of-fit \\
\hline $\mathrm{OS} \rightarrow \mathrm{KS}$ & .24 & 2.09 & .037 & $\mathrm{CMIN} / \mathrm{DF}=2.44$ \\
\hline $\mathrm{OS} \rightarrow \mathrm{PSI}$ & .35 & 3.45 & .000 & $\begin{array}{l}\mathrm{DF}=146 \\
\mathrm{CFI}=.93\end{array}$ \\
\hline $\mathrm{TS} \rightarrow \mathrm{KS}$ & .37 & 3.26 & .001 & $\begin{array}{l}P=0.000 \\
G F I=.90\end{array}$ \\
\hline $\mathrm{TS} \rightarrow \mathrm{PSI}$ & .21 & 2.14 & .032 & RMSEA $=.056$ \\
\hline $\mathrm{KS} \rightarrow \mathrm{PSI}$ & .22 & 3.24 & .001 & $x 2=353.601$ \\
\hline
\end{tabular}


SHS Web of Conferences

Table 4

Summary of Significant Indirect Effect of Variables

\begin{tabular}{|c|c|c|c|c|c|}
\hline \multirow{2}{*}{$\begin{array}{l}\text { Predictor } \\
\text { Variables }\end{array}$} & \multicolumn{3}{|c|}{ Process Innovation } & \multirow[b]{2}{*}{$\mathrm{H}$} & \multirow[b]{2}{*}{ Result } \\
\hline & $\begin{array}{l}\text { Direct } \\
\text { Effect }\end{array}$ & $\mathrm{H}$ & $\begin{array}{l}\text { Indirect } \\
\text { Effect }\end{array}$ & & \\
\hline $\begin{array}{l}\text { Organizational } \\
\text { Structure }\end{array}$ & .35 & Sig & .05 & Sig & Partial mediation \\
\hline $\begin{array}{l}\text { Technological } \\
\text { Support }\end{array}$ & .35 & Sig & .08 & Sig & Partial mediation \\
\hline
\end{tabular}

\section{DISCUSSION AND CONCLUSION}

The results of the study are in line with the knowledge-based view of the firm which emphasizes the importance of understanding the processes through which organizations access and utilize knowledge possessed by its individual members (Grant, 1996). Organizational structure can influence knowledge management processes through shaping patterns and frequencies of communication among organizational members, stipulating locations of decision-making and affecting efficiency and effectiveness in implementing new ideas (Zheng, Yang and McLean, 2010). It also corresponds with Penrose's (1959) opinion that the usefulness of organizational resources varies with changes in organizational knowledge and knowledge management serves as a key leverage point in organizations. One practical implication of this study is that the Iraqi textile factories should take cognizant and try to improve their knowledge sharing practices.

This study bear theoretical implications as it provide some insights in integrating the resourcebased view when applied in the Iraqi textile industry. It reveals that whereas the resources (knowledge) in the textile factories may be hierarchical (organizational structure), knowledge sharing may bring the factories one step closer towards organizational effectiveness (process innovation) by mediating the resources to process innovation. Further exploration is needed to examine this proposition. The social implication of this study for the Iraqi government which owns the factories is to enhance knowledge sharing activities in the factories in order to promote process innovation in the Iraqi textile industry.

One of the limitations of this study is that the study was done in one industry and in one middleeastern country, specifically in the Iraqi textile industries which limits generalizablity of the findings. To further test the organizational contexts of the model,future research are encouraged in the context of an Asian or developing countries or emerging economiesfrom which the measurement model was tested (Gold, Malhotra and Segars, 2001; Wong, 2005). The study can also be replicated in other industries as well as in public or private factories.

In conclusion, based on the survey among employees in the Iraqi textile industry, the results revealed that organizational structure and technological support positively and significantly influence knowledge sharing. Knowledge sharing was also found to be an important mediator between organizational structure, technological support and process innovation. The findings bear implications to the Iraqi government's call for innovation and knowledge management practices in the Iraqi textile industry. 


\section{REFERENCES}

Ahmed, P. K. (1998). Culture and climate for innovation. European Journal Of Innovation Management. Vol. 1(1), pp. 30-43.

Alavi, M. \& Leidner, D.E. (2001).Review: Knowledge management and knowledge and transfer of internal best practices. California Management Review. Vol. 40(3), pp. 154-174.

Barney, J. (1991).Firm resources and sustained competitive advantage. Journal of Management, Vol. 17, pp. 99-120.

Bender, S.\& Fish, A. (2000).The transfer of knowledge and the retention of expertise: The continuing need for global assignments. Journal of Knowledge Management. Vol. 4(2), pp.125-137.

Bennett, R.\& Gabriel, H. (1999). Organizational factors and knowledge management within large marketing departments: An empirical study. Journal of Knowledge Management. Vol. 3(3), pp. 212-25.

Capon, N., Farley, J. U., Lehmann, D. R., \&Hulbert, J. M. (1992).Profiles of product innovators among large U.S. manufacturers. Management Science. Vol. 38, pp. 157-169.

Cetindamar, D. \& Ulusoy, G. (2008).Innovation performance and partnerships in manufacturing firms in Turkey. Journal of Manufacturing Technology Management. Vol. 19(3), pp. 332-345.

Chen, C. J.\& Huang, J. W. (2009). Strategic human resource practices and innovation performance: The mediating role of knowledge management capacity. Journal Of Business Research.Vol. 62(1), pp. 104-114.

Claver-Cortés, E., Zaragoza-Sáez, P., \& Ortega, E, P. (2007). Organizational structure features supporting knowledge management processes. Journal of Knowledge Management. Vol. 11(4), pp. 45-57.

Conner, K. R., \& Prahalad, C. K. (1996). A resource-based theory of the firm: Knowledge versus opportunism. Organization Science. Vol. 7(5), pp. 477-501.

Crossan, M . M., \&Apaydin, M. (2010). A multi-dimensional framework of organizational innovation: A systematic review of the literature. Journal of Management Studies. Vol. 47(6), pp. 1154-1191.

Gold, A. H., Malhotra, A., \& Segars, A. H. (2001). Knowledge management: An organizational capabilities perspective. Journal of Management Information Systems. Vol. 18(1), pp. 185-214.

Damanpour, F. (1991). Organizational Innovation: A Meta-Analysis of Effects of Determinants And Moderators. Academy of Management Journal. Vol. 34(3), pp. 555-590.

Damanpour, F. (1996). Organizational Complexity and Innovation: Developing and Testing Multiple Contingency Models. Management Science. Vol. 42(5), pp. 693-716.

Davila, T, Epstein, M. J., \& Shelton, R. (2006). Making Innovation Work: How To Manage It, Measure It, And Profit From It. Upper Saddle River, NJ: Wharton School Publishing. 
Darroch, J. \& McNaughton, R. (2002).Examining the link between knowledge management practices and type of innovation. Journal of Intellectual Capital. Vol. 3(3), pp. 210-22.

Deal, T. A., Kennedy, A. A. (1982). Corporate Culture. Reading, MA: Addison-Wesley.

Ein-Dor, P.\& Segev, E. (1982). Organizational context and MIS structure: Some empirical evidence.MIS Quarterly. Vol. 6(3), pp. 55-68.

Eppler, M. \& Sukowski, O. (2000).Managing team knowledge: Core processes, tools and enabling factors. European Management Journal. Vol. 18(3), pp. 334-341.

Gerybadze, A ., Hommel, U.,Reiners, H.W.,\&Thomaschewski, D.(2010).R\&D, Innovation and Growth: Performance of the world's leading technology corporations. Innovation and International Corporate Growth, pp. 11-29.

Ghani, K. A., Jayabalan, V.\&Sugumar, M. (2002).Impact ofadvanced manufacturing technology on organizational structure. Journal of High Technology Management Research. Vol. 13, pp. 157175.

Gopalakrishnan, S. \& Damanpour, F. (1997).A review of innovation research in economics, sociology and technology management. Omega: The International Journal of Management Science. 25(1):15-28.

Grant, R.M. (1991). The resource-based theory of competitive advantage: Implications for strategy formulation.California Management Review.Vol. 33(3), pp. 114-35.

Grant, R. M. (1996). Prospering in dynamically-competitive environments: Organizational capability as knowledge integration. Organization Science. Vol. 7(4), pp. 375-87.

Holbert, R. I.\& Stephenson, M.T. (2003). The importance of indirect effects in media effects research: Testing for mediation in structural equation modeling. Journal of Broadcasting \& Electronic Media. Vol. 47(4), pp. 556-572.

Holsapple, C. W.\&Joshi, K. D.(2001). A formal knowledge management ontology: Conduct, activities, resources, and influences.Journal of The American Society For Information Science and Technology.Vol. 55(7), pp. 593-612.

Hung, R. Y. Y., Lien, B. Y. H., Fang, S. C., \& McLean, G. N. (2010). Knowledge as a facilitator for enhancing innovation performance through total quality management.Total Quality Management.Vol. 21(4), pp. 425-438.

Jarvenpaa, S.L. \& Staples, D.S. (2001).Exploring perceptions of organizational ownership of information and expertise. Journal of Management Information Systems. Vol. 18(1), pp. 151183.

Kennedy, A. M. (1983). The adoption and diffusion of new industrial products: a literature review. European Journal of Marketing. Vol. 17(3), pp. 31-88.

Kharabsheh, R. A. (2007). A model of antecedents of knowledge sharing. The Electronic Journal of Knowledge Management. Vol. 5(4), pp. 419-426. Available online at www.ejkm.com. 
Kim, S.\& Lee, H. (2006). The impact of organizational context and information technology on employee knowledge-sharing capabilities .Public Administration Review. Vol. 66(3), pp. 370-384.

Kogut, B. \& Zander, U. (1992).Knowledge of the firm, combinative capabilities, and the replication of technology. Organization Science, Vol. 3(2), pp. 383-97.

Lee, H. \& Choi, B. (2003).Knowledge management enablers, processes, and organizational performance: An integrative view and empirical examination. Journal of Management Information Systems. Vol. 20(1), pp. 179-228.

Martínez-León, M.\&Martínez-García, J. A. (2011).The influence of organizational structure on organizational learning. International Journal of Manpower. Vol. 32 (5/6), pp. 537-566.

Mohd, B. E.\& Zawiyah, M. Y. (2009). The relationship between knowledge sharing, employee performance and service delivery in public sector organization: A theoretical framework. $\underline{\text { Public }}$ Sector ICT Management Review. Vol.3(1), pp. 37-45.

Nonaka I., Toyama, R., \&Konno, N. (2000).Seci, Ba, and Leadership: a unified model of dynamic knowledge creation. Long Range Planning. Vol. 33, pp. 5-34.

Nonaka, I. (1991). The knowledge-creating company. Harvard Business Review. pp. 96-104 (Nov-Dec).

Nonaka, I.\& Takeuchi, H. (1995). The Knowledge-Creating Company: How Japanese Companies Create The Dynamics Of Innovation.USA: Oxford University Press.

Nonaka, I., Von Krogh, G., \& Voelpel, S. (2006). Organizational knowledge creation theory: Evolutionary paths and future advances. Organization Studies. Vol. 27(8), pp. 1179-1208.

O'Dell, C.\& Grayson, C. (1998). If only we knew what we know: identification organizational innovation: A systematic review of the literature. Journal of Management Studies. Vol. 47(6), pp. 11541191.

Ortt, J.R. \& van der Duin, P. A. (2008). The evolution of innovation management towards contextual innovation management. European Journal of Innovation Management. Vol. 11(4), pp. 522538.

Peteraf, M. A. (1993). The cornerstones of competitive advantage: A resource-based view. Strategic Management Journal.Vol. 14(3), pp. 179-191.

Prajogo, D. I., Power, D. J., \& Sohal, A. S. (2004). The role of trading partner relationships in determining innovation performance: An empirical examination, European Journal of Innovation Management.Vol. 7(3), pp. 178-186.

Rapert, M. I., \&Wren, B, M. (1998).Service quality as a competitive opportunity. Journal of Services Marketing. Vol. 2(3), pp. 223-235.

Robbins S.P. (1990). Organization Theory: Structure Designs and Applications (3th ed.). Englewood Cliffs, NJ: Prentice-Hall, Inc. 
Sher, P.J \& Lee, V.C. (2004).Information Technology as a facilitator for enhancing dynamic capabilities through knowledge management. Information \& Management. Vol. 41(8), pp. 933-945.

Smith, T. A. (2006). Knowledge management and its capabilities linked to the business strategy for organizational effectiveness. ProQuest-CSA.Vol. 68(1), pp. 143.

Stonehouse, G. H. \& Pemberton, J. D. (1999).Learning and knowledge management in the intelligent organization. Participation And Empowerment: An International Journal. Vol. 7(5), pp. 131-144.

Subramaniam, M. (2005). The influence of intellectual capital on the types of innovative capabilities.Academy of Management Journal. Vol. 48(3), pp. 450-463.

Teece, D. J. (1998). Capturing value from knowledge assets. California Management Review. Vol. 40(3), pp. 55-79.

Teece, D. J., Pisano, G. \& Shuen, A. (1997). Dynamic capabilities and strategic management.Strategic Management Journal. Vol.18, pp. 509-33.

Tippins, M.J. and Sohi, R.S. (2003).IT competency and firm performance: Is organizational learning a missing link? Strategic Management Journal. Vol. 24(8), pp. 745-61.

Wernerfelt, B. (1984). A resource-based view of the firm. Strategic Management Journal. Vol. 5(2), pp. 171-180.

Wong, P. K., \& He, Z. L. (2003). The moderating effect of a firm's internal climate for innovation on the impact of public R\&D support programs. International Journal of Entrepreneurship and Innovation Management. Vol. 3(5/6). p. 525-545.

Zheng, W., Yang, B., \& McLean, G. N. (2010).Linking organizational culture, structure, strategy, and organizational effectiveness: Mediating role of knowledge management. Journal of Business Research. Vol. 63 (7), pp. 763-771. 